\title{
RECENZJE
}

DANIEL MATUSIAK*

Uniwersytet SWPS

DOI: $10.26485 / \mathrm{PS} / 2017 / 66.3 / 6$

\section{Michał Wenzel, Labour protest in Poland. Trade unions and employee interest articulation after socialism, Frankfurt am Main: Peter Lang 2016, ss. 205.}

Polskie protesty robotnicze doczekały się już wielu opracowań. W okresie przed 1989 rokiem związki zawodowe były opisywane dwojako. Z jednej strony jako instytucjonalne narzędzia aparatu władzy socjalistycznej, kiedy to klasa robotnicza miała pełnić kierowniczą - zgodnie z linią ideologiczną - rolę w państwie. Albo, z drugiej strony, jako przejawy istnienia tłumionego społeczeństwa obywatelskiego. Po 1989 roku związki zawodowe nadal stanowią wdzięczny obiekt badań w związku ze zmianą ich roli społecznej w regularnego interesariusza na wolnym rynku ekonomicznym. Praca Michała Wenzla jest bodaj jedyną pozycją opisującą polskie protesty robotnicze, w której uwzględnia się obie te perspektywy czasowe. Ale nie tylko ta kwestia zasługuje na wyeksponowanie. Niepoślednią część rozważań autor poświęca roli organizacji pracowniczych w trakcie samej tranzycji systemowej. Wydaje się to szczególnie uzasadnione w kontekście znaczącej zmiany roli społecznej, jaka w tym okresie była udziałem związków zawodowych.

W rozdziale I autor omawia kwestie teoretyczne i metodologiczne. Kluczowym elementem teoretycznego opisu protestów robotniczych w Polsce po II wojnie światowej jest system polityczny, w ramach którego działają podmioty społeczne, oraz jego zmiana. Pojęcia teoretyczne nabierają różnych znaczeń w odniesieniu do systemów komunistycznego i demokratycznego, a rola związków zawodowych zmieniła się znacząco w czasie transformacji. Z biernych realiza-

\footnotetext{
* Mgr, Interdyscyplinarne Studia Doktoranckie; e-mail: dmatusiak@st.swps.edu.pl
} 
torów polityki partii/państwa przeobrażają się w masowe ruchy niezadowolenia społecznego, by w demokracji stać się jedną z wielu grup interesu. Jednocześnie autor podkreśla problemy metodologiczne związane $\mathrm{z}$ dotarciem do danych empirycznych opisujących protesty społeczne przed 1989 rokiem, które w dobie socjalizmu były ściśle kontrolowane przez aparat państwowy.

Rozdział II opisuje główne fale protestów i ich konsekwencje w Polskiej Rzeczypospolitej Ludowej. W tym okresie Polską wstrząsały fale protestów społecznych, ze zwiększoną siłą swoje niezadowolenie demonstrowały różne grupy społeczne. Niepokoje pracownicze stały się realnym zagrożeniem dla władz w drugiej połowie lat 70. XX wieku. Wywierały one coraz większy wpływ na decyzje polityczne, a ich liderzy stawali się obiektami działań operacyjnych służb państwowych. Organizatorzy protestów pojawiali się również w poszczególnych zakładach pracy, wtedy przecież państwowych. Zmiany te miały swoje odbicie w okresie po transformacji. Umiejętności i kadry rozwinięte w późnym socjalizmie wykorzystywano do organizowania protestów również w nowym kontekście społeczno-ekonomicznym.

Rozdział III jest poświęcony zmianom w strukturze związków zawodowych $\mathrm{w}$ dobie transformacji systemowej. Reformy polityczne i ekonomiczne zmieniły społeczeństwo i jego instytucje. Zmiany te znacząco wpłynęły również na związki zawodowe. Członkostwo w związkach spadło, ale spadek ten wyglądał różnie w zależności od sektora gospodarki (w największym stopniu dotknął sektor usług). Aby ukazać te trendy, autor używa danych z sondaży CBOS przeprowadzonych w latach 1984-2012. Ponadto prezentuje dane dotyczące postaw opinii publicznej w stosunku do działań związków zawodowych, wykazując zwiększoną akceptację społeczną dla różnych form protestu i oczekiwania dotyczące kształtowania rzeczywistości społeczno-politycznej przez związki zawodowe.

W rozdziale IV przedstawiono maksymalnie szeroki obraz akcji protestacyjnych zorganizowanych w latach 1989-2011. Autor szczegółowo opisuje działania pracowników po zmianie systemowej w 1989. Stosuje przy tym jedną technikę analizy do opisu wszystkich zarejestrowanych protestów z tego okresu. Związki zawodowe okazały się najbardziej aktywnymi organizatorami tych wydarzeń przed, w czasie i po transformacji. Używały wielu metod, często działając we współpracy z innymi podmiotami społecznymi i instytucjonalnymi. Opis poszczególnych protestów uwzględnia charakterystykę społeczną uczestników, ich liczbę, żądania, cele i taktykę. Dodajmy, że transformacja nie wpłynęła znacząco na modus operandi związków zawodowych w zakresie organizowania demonstracji i strajków. 
Rozdział V koncentruje się na porównaniu protestów w sektorach publicznym i prywatnym. Autor identyfikuje gałęzie przemysłu, w których związki są najbardziej aktywne w organizowaniu protestów, oraz proponuje typologię protestów. Związki zawodowe pozostają nadal silne w sektorze publicznym i tam właśnie koncentrują się ich działania. W sektorze prywatnym natomiast są znacznie słabsze, organizują mniej protestów i wydają się koncentrować na poziomie konkretnego przedsiębiorstwa.

Publiczne aktywności polskich związków zawodowych nie ograniczają się do postulatów ekonomicznych. Dynamika protestów o nieekonomicznym podłożu została opisana w rozdziale VI. Przywódcy związków, na różnych etapach naszej najnowszej historii, stawali się politykami, a nawet ustawodawcami. Poza tym dostrzec można również zinstytucjalizowany wpływ związków zawodowych na partie polityczne, zarówno po prawej, jak i lewej stronie sceny politycznej. Zdarzało się więc, że związki zawodowe organizowały demonstracje czy strajki wspólnie z partiami politycznymi. Takie protesty miały i mają na celu artykulację żądań politycznych, którym czasami towarzyszą żądania ekonomiczne.

W rozdziale VII autor zamieszcza empiryczny test efektywności działalności protestacyjnej związków zawodowych w czasie transformacji. Stawia hipotezę, że związki miały istotny wpływ na reformy państwowe. Empiryczny pomiar efektu protestów na podejmujących decyzje jest wyjątkowo trudnym zadaniem. Związek przyczynowo-skutkowy pomiędzy żądaniem związków zawodowych a decyzją władzy może nie być bezpośredni, poza tym od samego protestu do decyzji, na którą wpłynął, może upłynąć bardzo dużo czasu. Ponadto powiązanie to może nie być oczywiste i wyraźne: władze mogą wprowadzać lub zmieniać politykę pod wpływem związków zawodowych, jednocześnie temu zaprzeczając lub, wręcz przeciwnie, mogą tylko pozornie spełniać żądania protestujących. $\mathrm{Z}$ tych względów niezbędna jest każdorazowa głęboka analiza protestów. Autor porównuje mobilizację w dwóch okresach. Pierwszy to początkowa faza rządów Jerzego Buzka (listopad 1997-grudzień 1998). W tym okresie protesty w Polsce osiagnęły najwyższy zanotowany poziom. Rząd wprowadził znaczące reformy, które nie spodobały się wielu grupom interesów i wywołały kontrowersje. By zbadać żądania i odpowiedź władz, autor powiązał obie te sprawy. Drugim okresem są rządy Leszka Millera (listopad 2001-grudzień 2002), kiedy to reformy nie były wprowadzane.

W VIII rozdziale autor prezentuje perspektywę porównawczą. Pokazana została trajektoria mobilizacji społecznej w Polsce i na Węgrzech, w krajach o podobnej historii przemian - transformacja państwa socjalistycznego zainicjowana została przez konsensus pomiędzy elitami ancien régime'u i opozycji. 
Początkowo, po wprowadzeniu nowego systemu, społeczeństwo polskie było dużo bardziej zmobilizowane niż węgierskie. Później te trendy uległy odwróceniu, gdyż protesty na Węgrzech wzrosły do poziomu o wiele wyższego niż ten zanotowany w Polsce. W jakimś stopniu przypisywać to można czynnikom ekonomicznym: stopniowa poprawa polskiej ekonomii obniżyła presję, podczas gdy trwający na Węgrzech kryzys wzmagał niezadowolenie społeczne. Poza czynnikiem ekonomicznym na takie tendencje wpływ miały i inne elementy zidentyfikowane w omawianej książce. Zdaniem autora kluczowy dla rozwoju podmiotów zbiorowych, zarówno w Polsce, jak i na Węgrzech, był skład elit podczas obrad okragłego stołu. W Polsce dominacja robotniczych związków zawodowych w protestach może być tłumaczona ich rolą przed i po transformacji. Z kolei na Węgrzech elitę opozycyjną zdominowały ugrupowania polityczne formowane głównie przez podmioty klasy średniej. Wegierskie protesty były bardziej polityczne i względnie często prowadzone przez profesjonalistów.

Autor zachowuje neutralność w analizowaniu działań związków zawodowych. Nie ocenia wpływu związków na reformy ekonomiczne. Nie udziela też jednoznacznej odpowiedzi na pytanie, czy działania związków przyczyniły się do zredukowania nierówności dochodów i napięcia instytucjonalnego, a więc czy wpłynęły na kierunek transformacji. Zdarzało się, o czym przypomina autor, że związki zawodowe stanowiły przeszkodę w skutecznym przeprowadzaniu transformacji, a niekiedy nawet przedsiębiorstwa zarządzane przez związi zawodowe upadały. Poszczególne protesty mogły zatem przynosić lepsze lub gorsze efekty, jednak ich ocena możliwa była dopiero po fakcie, w długoterminowej perspektywie. Ponadto ocena efektów wielu protestów może różnić się w zależności od przyjmowanej perspektywy: lokalnej - a więc konkretnego przedsiębiorstwa, czy globalnej - gospodarki kraju, a także ze względu na ukazanie punktu widzenia różnych obywateli dotkniętych strajkami - uczestników i organizatorów.

Autor nie ocenia poszczególnych metod i strategii protestu, jakiekolwiek kategoryzowanie zakłóceń uznaje za problematyczne. Strajki, demonstracje, blokady dróg charakteryzowały się różnym nasileniem uciążliwości. Większość z nich była legalna i pokojowa, ale niektóre pociaggały za sobą przemoc i przestępczość. Poziom akceptacji przemocy w akcjach związkowych mógł się zmienić w ostatnim dwudziestopięcioleciu, równolegle do generalnych zmian nastawienia społecznego. W okresie tranzycji związki zawodowe były traktowane w specjalny sposób ze względu na ich rolę w opozycji. Później ta ich uprzywilejowana pozycja uległa osłabieniu. 
Publikację uzupełnia wyczerpujący aneks metodologiczny uzasadniający konieczność zastosowania różnych źródeł danych i technik w przypadku badań okresów przed i po 1989 r.

Labour Protest in Poland zasługuje na uwagę z kilku przyczyn. Po pierwsze, o czym już wspominałem, ze względu na porównanie polskich protestów robotniczych w szerokiej perspektywie czasowej, przed i po transformacji systemowej. Po drugie, ze względu na poświęcenie uwagi zmianom doświadczanym przez związki zawodowe w trakcie samej tranzycji. Trzecim ważnym wymiarem prezentowanej analizy jest przyjęcie polsko-węgierskiej perspektywy porównawczej oraz umiejscowienie procesów zachodzących w Polsce na tle doświadczeń regionu. Bezapelacyjnym atutem pracy Michała Wenzla jest bogactwo empiryczne. Źródła danych pochodzą z lat 1984-2012 i same w sobie stanowią imponujący zbiór. Spójna analiza wymagała twórczego podejścia do różnorodnych technik i narzędzi pozyskiwania danych. Książka ta z pewnością stanie się ważnym punktem odniesienia dla wielu polskich badaczy społecznych, przede wszystkim zajmujących się związkami zawodowymi czy stosunkami pracy w Polsce.

Publikacja Labour protest in Poland. Trade unions and employee interest articulation after socialism została wydana przez wydawnictwo Peter Lang jako czwarty tom redagowanej przez Radosława Markowskiego serii Warsaw Studies in Politics and Society. 